\title{
Proposing a Supply Chain Collaboration Framework for Synchronous Flow Implementation in the Automotive Industry: A Moroccan Case Study
}

\author{
Imane Ibn El Farouk ${ }^{1}$, Imane Moufad ${ }^{2}$, Youness Frichi ${ }^{2, *}\left(\mathbb{D}\right.$, Jabir Arif ${ }^{2,3}$ and Fouad Jawab ${ }^{2}(\mathbb{D}$ \\ 1 Laboratory of Studies and Research in Economics and Management, Chouaib Doukalli University, \\ El Jadida 24000, Morocco; imane-ibn-el-farouk@outlook.com \\ 2 Laboratory of Technologies and Industrial Services, High School of Technology, Sidi Mohamed Ben \\ Abdellah University, Fez 30000, Morocco; imane.moufad@usmba.ac.ma (I.M.); jabir.arif@usmba.ac.ma (J.A.); \\ fouad.jawab@usmba.ac.ma (F.J.) \\ 3 Laboratory of Modeling and Optimization of Industrial Systems, National School of Applied Sciences, \\ Tetouan 93040, Morocco \\ * Correspondence: youness.frichi@usmba.ac.ma; Tel.:+212-670144244
}

Received: 30 July 2020; Accepted: 2 September 2020; Published: 7 September 2020

\begin{abstract}
The present paper reports on studying synchronous flow implementation, as a lean supply chain tools, through a collaborative relationship with suppliers. This involves consolidating with a new contribution to the development and application of a supply chain collaboration framework between automotive constructor and first-tier equipment suppliers to achieve the synchronous flow of components. The objective is to provide the automotive companies with a decision-making tool for selecting strategic suppliers to collaborate with, examining the collaboration context in terms of motivators, drivers, and barriers and evaluating the collaboration performance. Therefore, our contribution is structured as follows. As a first step, an overview of papers reporting on collaboration, lean supply chain, and synchronous flow is provided to identify the key elements of successful collaboration relationships. As a result, a preliminary framework is elaborated. The second step described the case study of a leading automotive firm "RENAULT" and its suppliers in Morocco. Based on semi-structured interviews conducted with participants from these companies, the preliminary framework was improved. The next section discusses the obtained results as well as the improved framework. Finally, conclusions and suggestions for further works are included.
\end{abstract}

Keywords: lean supply chain; supply chain collaboration; synchronous flow; framework; Morocco

\section{Introduction}

The automotive industry is becoming increasingly competitive due to, among others, the evolving nature of the products, the variety of models, and customer requirements. The tough competitiveness has pushed automotive manufacturers to revisit various established strategies and reassess their viability under the lean lens [1]. The implementation of lean practices aims at eliminating wastes and reducing inventory costs [2]. Lean tools applied in the automotive industry include, but are not limited to, cellular manufacturing, 5S, total productive maintenance, work standardization, quality management, visual control, statistical processes control, pull production, long-term relationships with suppliers, and synchronous flow [1]. Particularly synchronous flow in the automotive industry has gained importance with the increasing complexity and diversity of components and sub-assemblies that suppliers deliver to their contractors. The sequence of arrival of the spare parts on the assembly line must be perfectly synchronized to allow a coherent, efficient, and effective assembly. The synchronous flow approach implies absolute respect of the requisition time-i.e., the manufacturer's advance 
notice to its suppliers so that they can manufacture the planned spare parts, in the right sequence, at the right time and with the correct quantity. The whole vehicle assembly relies on the timely delivery of components. Sequential Just In Time (JIT) makes it necessary for suppliers to transport customer-ordered components in the same sequence and synchronized with the final assembly process [3]. Synchronous flow is qualified as a high JIT supply strategy and requires a robust logistical organization. It takes the JIT approach to the extreme.

Numerous studies have shown the benefits of implementing lean practices in the automotive industry [1]. However, for a company, being lean is not sufficient to gain full competitive advantages, the company's suppliers are also required to pursue a lean strategy for better performance [4]. Hence, lean tools and practices must be extended down through the supply chain to achieve a lean supply chain [5]. It focuses on continuous improvement through the elimination of non-added-value activities along the supply chain [4]. Thus, the lean methods, which are extensively applied in the automotive industry, need to be extended to the auto-component suppliers so that the whole supply chain becomes lean [1]. For that purpose, several authors have identified the collaboration with suppliers as the main factor for the successful implementation of lean tools and practices among the supply chain [6,7]. In this paper, the aim is to study the possibility of implementing synchronous flow, as a lean supply chain tool, via the collaboration with suppliers. To this end, a framework of supply chain collaboration is established in the automotive industry for implementing the synchronous flow approach. The purpose of this framework is to provide the automotive firms with a decision-making tool for, first, selecting strategic suppliers to collaborate with; second, examining the collaboration environment in terms of key drivers and barriers; third, assessing the collaboration performance regarding the synchronous flow approach.

Seeking competitive advantages, most of the leading automotive firms relocate to emerging markets such as Morocco due to the governments' overall low cost of manufacturing and incentive measures. For instance, the Moroccan government has structured the automotive industry sector around industrial ecosystems that group together industry leaders and small and medium-sized enterprises (SMEs) in industrial areas. The objective is to create genuine technological fields around targeted collaboration, leading to long-term supply contracts and technology transfers [1].

Thanks to this strategy, the Moroccan automotive industry has reached sustained growth levels over the last few years. Its performance is particularly remarkable in terms of exports and job creation. Given the strategic importance of such an industry, investigating the benefits of adopting and applying lean practices, in particular synchronous flow, is worthwhile. Thus, we aim to develop the supply chain collaboration framework based on the literature, and a case study of an international automotive firm operating in Morocco and its suppliers.

It is important to note that this paper is based on a preliminary analysis of an article published in a conference proceeding [8]. In this paper, more analysis and insights are provided that go beyond the conference paper regarding implementing the synchronous flow in the automotive firm.

The remainder of this paper is organized as follows. The next section reviews the literature on the lean supply chain, collaboration, and synchronous flow to provide an overview of key components of successful supply chain collaboration. Section 3 presents the working methodology, which consists of two main subsections. The first one describes the studied case study of a leading automotive firm and its suppliers in Morocco. The second subsection describes the data collection process, which relied on semi-structured interviews. Section 4 provides the research results and the elaborated framework of supply chain collaboration. Section 5 discusses the obtained results as well as the elaborated framework. The last section concludes the paper and gives insights into future research.

\section{Literature Review}

In this section, a literature review is provided on supply chain collaboration, its drivers, motivators, benefits, and the key elements in lean synchronization with suppliers. The literature review helped us 
establish a preliminary framework for supply chain collaboration, particularly for the implementation of lean practices.

\subsection{Supply Chain Collaboration}

Supply chain collaboration admits different definitions [9-11]. However, one of the most widely adopted definitions of supply chain collaboration is "two or more independent companies work jointly to plan and execute supply chain operations with greater success than when acting in isolation" [12]. Some researchers underline that the term collaboration is chosen to describe the close cooperation among autonomous partners engaged in a joined initiative to effectively meet the end customer's needs with minimum cost $[13,14]$. Collaboration occurs when two or more organizations exchange information, share responsibilities for planning, manage, execute, and monitor supply chain performance [14-16]. Singh et al. [17] consider that supply chain collaboration is a responsible relationship among partners, who share information, develop a collective performance, and reconfigure business practices to improve profit margin. Recent literature is focusing on an improved characterization of the collaborative supply chain. According to Marqui et al. [18], collaboration is much more complicated than a set of techniques and systems; several behaviors and characteristics are required to make the collaborative supply chain a reality. The authors also consider cooperating and coordinating operations with strategically selected partners to achieve collaboration within the supply chain. However, cooperation is necessary, but not a sufficient condition to achieve coordination, which is necessary, but not a requirement to achieve collaboration. Additionally, Ma et al. [19] have added that, besides collaboration, there are many other concepts currently used that involve an interest in collaborative relationships, such as coordination, cooperation, alliance, and joint venture, as outlined in Figure 1. According to Spekman et al. [20], cooperation is where firms exchange basic information and have some long-term relations with a limited number of critical suppliers or customers. In addition, a higher degree is coordination involving a continuous flow of important and critical information provided using information technology. Collaboration is a stage higher than coordination that requires a high level of commitment, trust, and information-sharing [21,22]. Therefore, cooperation, coordination, and collaboration are different concepts because they involve various levels of trust and commitment [23].

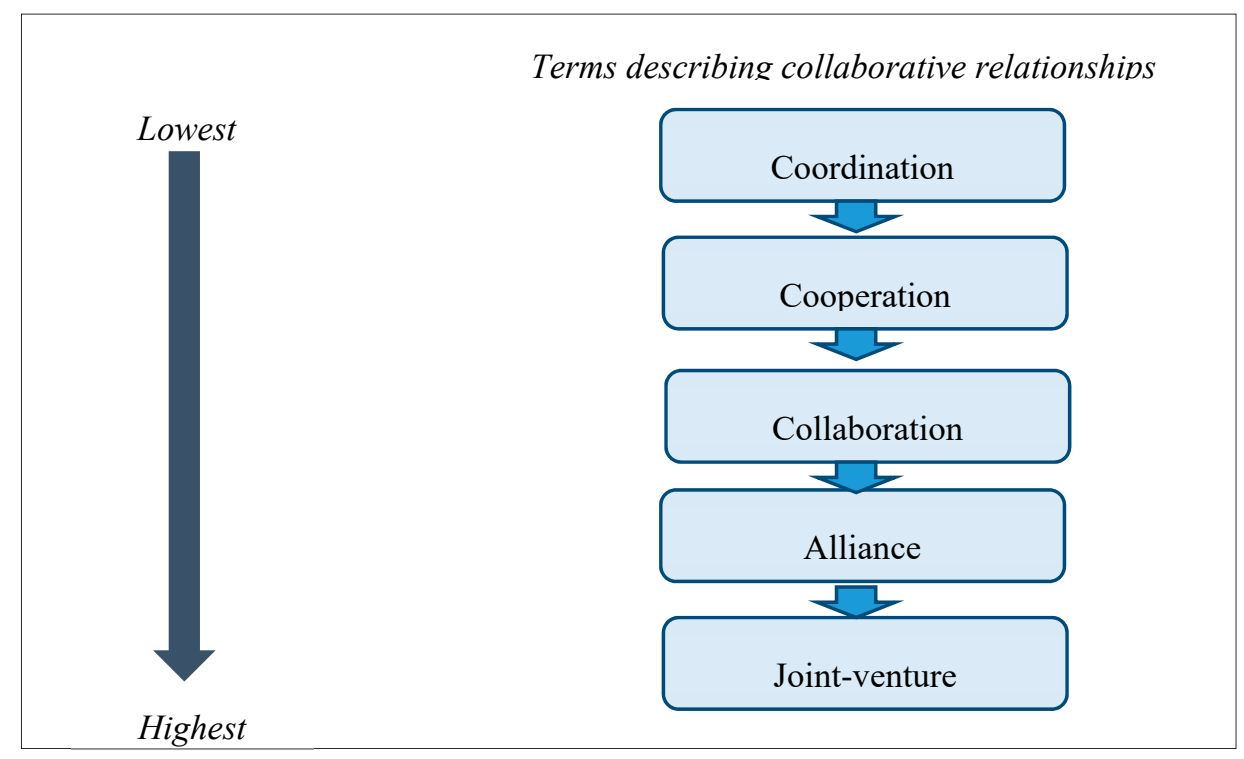

Figure 1. Levels of collaboration. Source: adapted from Ma et al. [19].

Furthermore, we align with the point of view that collaboration relationships occur when more than one organization work together for a mutual objective and distinguish collaboration from coordination, which serves the following functionalities: establishing collaborative organizations, 
collecting and sending information, planning collaborative activities, identifying the allocation of demand, assessing performance, and managing changes [12]. In this respect, there are two dimensions of supply chain collaboration [24]: vertical collaboration, which involves collaboration between suppliers and customers; horizontal collaboration, which includes collaboration with competitors and other supply chain actors.

\subsection{Drivers of Collaborative Relationships}

The drivers represent the key factors that make collaboration more successful [17]. Nevertheless, in the implementation process, it is necessary to analyze the presence of barriers that may hinder the initiative's implementation or the achievement of expected benefits [25]. This literature review has not discussed the barriers because they are overcome if the drivers are available. According to Marqui et al. [18], the main characteristics required for collaborative relationships in the supply chain are communication, interdependence, transparency, flexibility, leadership, synchronized decision-making, commitment, and organizational culture compatibilities. Additionally, Freitas et al. [25] have proposed to characterized the supply chain collaboration using five elements, which include appropriate performance system, information sharing, decision synchronization, incentive alignment, and streamlined inter-enterprise business processes. In the same light, Mofokeng and Chinomona [10] have outlined seven key dimensions of collaborative relationships, namely information sharing, decision synchronization, incentive alignment, resource sharing, communication, and joint knowledge creation.

In the context of the automotive industry, information sharing, joint decision making, and electronic data interchange positively influence the supply chain [26,27]. Additionally, trust is considered an essential mechanism in collaborative relationships [25]. Developments in information technology are making it easier for companies to share planning information [17,28]. Effective collaborative planning depends on the quality of the information shared between the companies [29]. In this context, Panahifar et al. [30] talked about enablers that can improve collaboration. They studied the following enablers: trust, information readiness, and secure sharing of information. Based on these studies, we compiled Table 1, which summarizes the drivers of collaborative relationships and their founding references.

Table 1. Drivers of collaboration in the supply chain.

\begin{tabular}{cll}
\hline \multicolumn{1}{c}{ Drivers of Collaborative Relationships } & Reference \\
\hline$\checkmark$ & Communication & \\
$\checkmark$ & Interdependence & \\
$\checkmark$ & Transparency & [18] \\
$\checkmark$ & Flexibility & \\
$\checkmark$ & Leadership & \\
$\checkmark$ & Synchronization & \\
$\checkmark$ & decision-making & [25] \\
$\checkmark$ & Commitment & \\
$\checkmark$ & Organizational culture compatibility & \\
\hline$\checkmark$ & Appropriate performance system & \\
$\checkmark$ & Information sharing & \\
$\checkmark$ & Decision synchronization & \\
$\checkmark$ & Incentive alignment & \\
$\checkmark$ & Streamlined inter-enterprise business processes & \\
$\checkmark$ & Information sharing & \\
$\checkmark$ & Goal congruence & \\
$\checkmark$ & Decision synchronization & \\
$\checkmark$ & Incentive alignment & \\
$\checkmark$ & Resource sharing & \\
$\checkmark$ & Communication & Joint knowledge creation \\
$\checkmark$ & & \\
\hline
\end{tabular}


Table 1. Cont.

\begin{tabular}{clc}
\hline \multicolumn{1}{c}{ Drivers of Collaborative Relationships } & Reference \\
\hline$\checkmark$ & Information sharing & \\
$\checkmark$ & Joint decision making & [26] \\
$\checkmark$ & Electronic data interchange positively & \\
$\checkmark$ & Influences operational performance of SC & [30] \\
\hline$\checkmark$ & Trust & [17] \\
$\checkmark$ & Information readiness & \\
$\checkmark$ & Secure sharing of information & \\
\hline$\checkmark$ & Commitment & \\
$\checkmark$ & Trust & \\
$\checkmark$ & Competition, Technology & \\
$\checkmark$ & Innovative SC process & \\
$\checkmark$ & Joint long-term relations & \\
$\checkmark$ & Better Information sharing & \\
$\checkmark$ & Joint decision making & \\
$\checkmark$ & Incentive alignment & \\
$\checkmark$ & Resource sharing & \\
$\checkmark$ & Appropriate Performance measure, Globalization & \\
\hline$\checkmark$ & Quality of information shared between the companies \\
$\checkmark$ & Trust & \\
$\checkmark$ & Information readiness and secure sharing of information & \\
\hline
\end{tabular}

\subsection{Motivators of Collaborative Relationships}

According to Freitas et al. [14], the motivators behind adopting collaborative relationships can be classified into two categories:

1. Economic motivators: represent market-related factors that influence the supply chain and push companies to adopt collaborative initiatives. They include [25]:

- Intense competition: the fierce inter-company competition and the emergence of new firms are forcing companies to develop new practices to improve their efficiency and ensure competitiveness.

- Product and market characteristics: a consistent element in collaborative relationships is the challenge for companies to reduce their life cycle.

- Economic globalization: it represents a significant factor in the adoption of collaborative relationships.

- Market reaction: as companies establish collaborative initiatives in their markets, it can help them boost their competitiveness, and then other firms see the need to follow them.

2. Organizational motivators: they are internal factors related to the company's organization and among the supply chain companies that lead to the adoption of collaborative initiatives. Organizational motivators comprise supply chain problems, previous experiences, and pressure from the partners. They are associated with the companies' structure, either internally or between companies, which allows for the adoption of collaborative relationships [14].

\subsection{Benefits of Collaborative Relationships}

Another important element in the process of implementing collaborative relationships is benefits. They represent the efficiency and effectiveness offered to the overall supply chain [17]. Additionally, collaboration in the supply chain can improve performance by minimizing the demand and supply uncertainty, improve revenue, reduce cost, and increase flexibility [31]. Many studies have found that a higher level of supply chain collaboration can improve the firms' performance, especially in logistics activities [32,33]. Other studies have identified cost reduction, profit, forecast accuracy, and inventory 
control as the benefits of collaboration in the supply chain $[10,15]$. As a conclusion of a literature review by Singh et al. [17], the authors listed the benefits of supply chain collaboration as follow: inventory turns, increased revenues, costs reduction, product availability, on-time delivery, responsiveness, advanced economy, capital utilization, decreased time to market, improved quality, reduced inventory, improved customer services, better supply chain relationships, increased information sharing, accurate forecasting, and enhanced competitiveness.

\subsection{Key Elements in Lean Synchronization with Suppliers}

From reducing lead times, increasing productivity, reducing inventory, improving quality, and making efficient use of space, lean has helped various organizations achieve their operational objectives [34]. Lean synchronization or JIT works toward satisfying customers' demands in the right quality, time, and eliminating any activity that does not add value to the production process. Synchronous supply is when the requisition is sent to the supplier a few hours in advance. The brevity of the anticipation of this requisition has led to the setting up of specific organizations, particularly in the automotive industry $[35,36]$. The increasing rate of adopting lean practices in the supply chain has been noticed, particularly in the automotive industry. This has created a need for geographical proximity of the supplier to the assembler. Here we provide the key elements for effective implementation of lean supply chain practices [37]:

- Collaboration with suppliers: the implementation of lean practices relies primarily on long-term and reliable relationships with suppliers. Thus, the success of lean is based on collaboration with suppliers. Tuli and Shankar [6], and Huang et al. [7] have identified important drivers of significant stakeholders' collaboration that include: trust, information sharing, goal congruence, resource sharing, coordinating actions, and willingness to collaborate. Boonsthonsatit and Jungthawan [38] argued that suppliers' participation in lean, which results from collaboration, can improve the company's performance and present opportunities to gain competitive advantages.

- Training: when a manufacturer is aware of the benefits of collaboration with its suppliers, it promotes the application of collaboration in the supply chain through training initiatives for the benefit of the suppliers. Training initiatives end up by suppliers appreciating how important collaboration is. Manfredsson et al. [2] have studied the outcomes of manufacturers providing training and sharing knowledge with its suppliers on promoting collaboration. The authors found that suppliers' commitment and willingness to learn are crucial for the excellent implementation of lean practices. Training is proven to increase engagement regarding the application of lean tools and structure the way of working for continuous improvement [39].

- Resources: insufficient resources do not allow the implementation of lean supply chain practices. Some companies use expert consulting to implement these practices, so resources for consulting are essential [40].

- Proximity: JIT delivery is an obvious and important outcome of lean production. However, it is challenged by geographic dispersion. Thus, suppliers with proximity are perfect candidates for JIT delivery [41].

- Other factors: Other key factors for succeeding in applying the lean approach include leadership supporting initiatives, linking improvement to strategic goals, practicing continuous improvement daily, employee involvement and satisfaction, continuous learning, etc. [11,42].

From this literature review, we have drawn in Figure 2 the preliminary framework, based on lean practices, for implementing the synchronous flow approach via supply chain collaboration.

The present framework provides the key elements of successful collaboration relationships. The first step concerns the analysis of motivators and drivers. The second step involves the selection of lean supply chain practices. The third one concerns examining the collaboration environment in terms of key elements in lean synchronization, namely the proximity, the information-sharing 
requirements, and the resources requirements. Once all steps are validated, we implement and assess the collaboration performance regarding the synchronous flow approach.

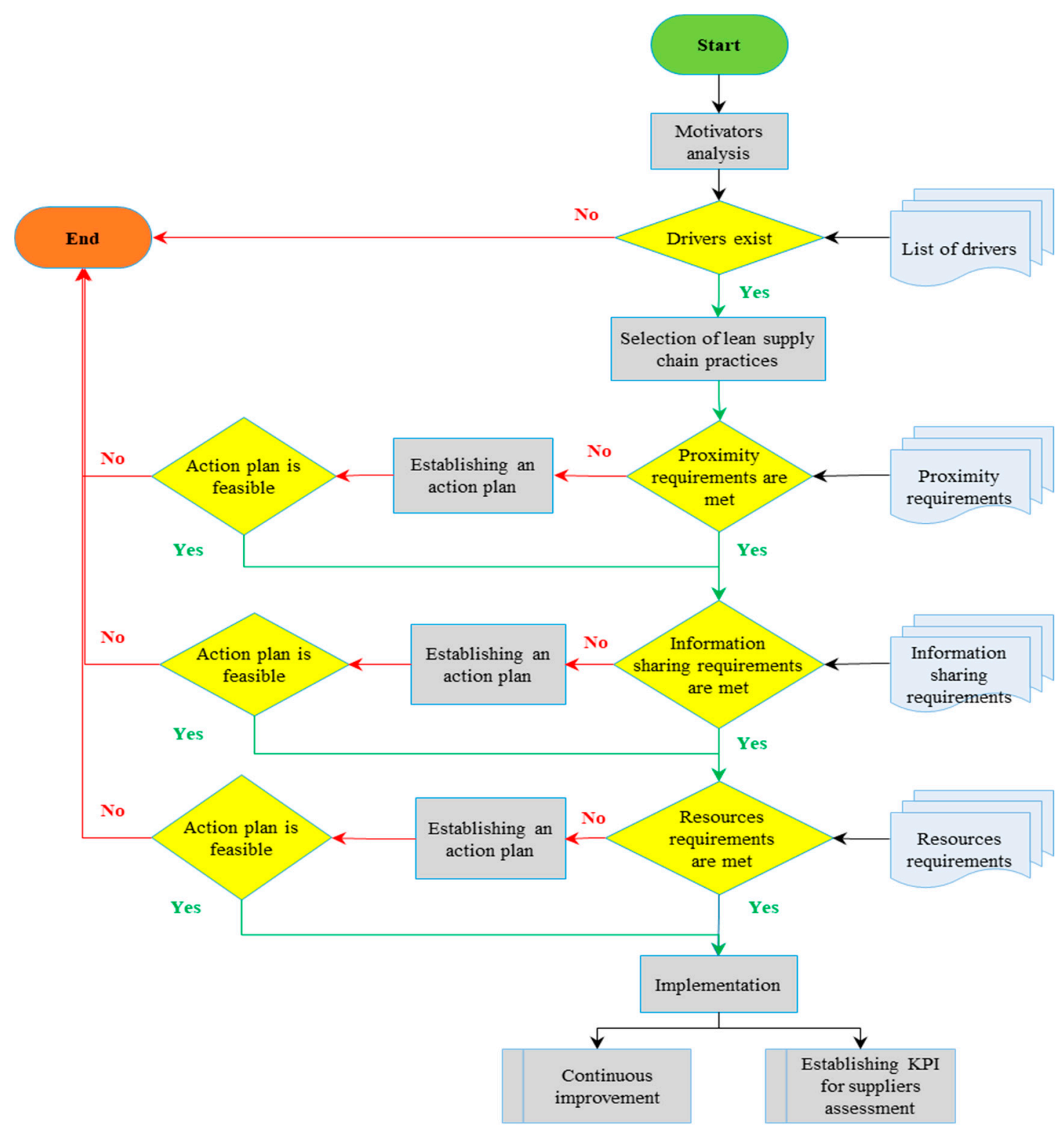

Figure 2. A preliminary framework for supply chain collaboration in the implementation of lean practices.

\section{Materials and Methods}

The methodology proposed in this paper is organized around the following steps (see Figure 3). The proposal is firstly based on a literature review to identify the motivation factors, the drivers, the benefits of collaborative relationships, and the key elements of lean synchronization. As a result, a preliminary framework is developed. Secondly, an analysis of a case study of five companies is conducted to highlight the automotive industry's context and determine the specific elements of collaboration to enrich the preliminary framework. The results of these two steps allow for the proposition of a revised framework adapted to the case study context. 


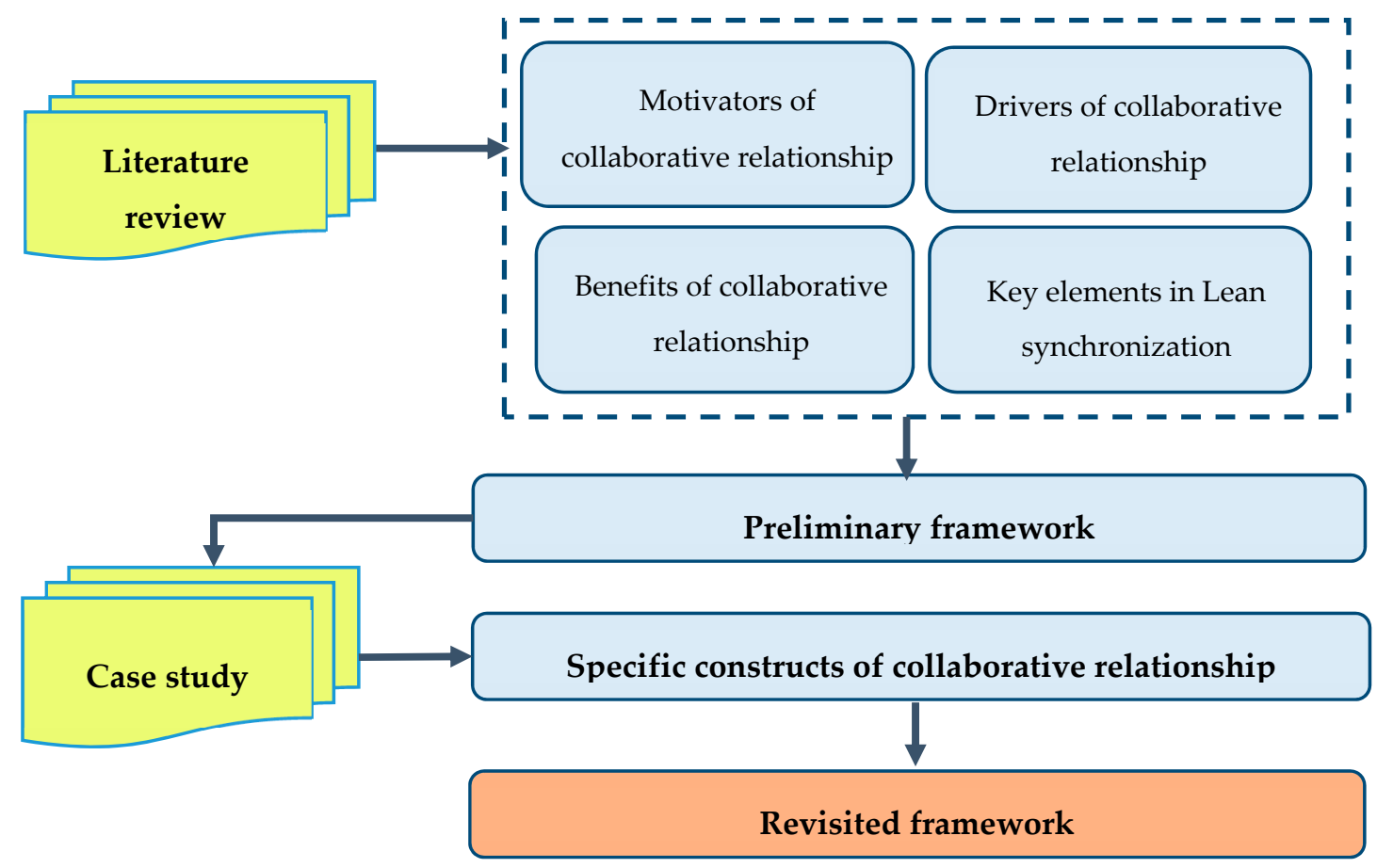

Figure 3. Steps of the proposed methodology.

\subsection{Case Study Description}

This study aims to develop a framework for collaboration between automotive constructors and first-tier equipment suppliers to achieve a synchronous flow of components. The basic idea is to synchronize the components' deliveries and the vehicle assembly flow to reduce or eliminate parts inventory in the manufacturer's plant. According to Piekkari et al. [43] and Seawright and Gerring [44], the single holistic case-study is appropriate to explore phenomena within a single unit of analysis in a complex context. Case study research is mostly used to examine and understand multiple complex issues. Besides, in a holistic and in-depth investigation, case study research is widely recommended as a robust research method [45]. Besides, according to Jasti and Kodali [46], the case study is considered as the most famous empirical research methodological approach in the lean research field.

This research has an applied, qualitative, and exploratory nature. It is organized on a single case study made up of one of RENAULT's automobile plants and five of its first-tier component suppliers. To save confidentiality, we have named them A, B, C, D, and E. All of them play an essential role in RENAULT's supply chain because of the vitality and criticality of the components they supply. The characteristics of the five studied suppliers' companies are provided in Table 2.

Until the study time, the five first-tier component suppliers were working under a traditional push flow. To provide a plan with subassembly, suppliers follow a daily firm order received from RENAULT's planning unit, as explained in Figure 4. (1), the supplier has three days as notice to plan, manufacture, and deliver the order (2), (3), (4). Firm order considers the initial sequence of vehicles, introduced in sheet metal, increased by a safety margin. Since all components are used in the assembly line, and regarding the diversity level, internal picking activities are used to supply the workstations following the sequence of vehicles introduced in the assembly line (5), (6). Finally, empty packaging is returned to the customer (6). Figure 4 shows this mechanism and the location of inventory in the plant. So, the main factor that motivated the study is that push flow may cause a high inventory level, especially in an uncertain demand context. Indeed, uncertainty comes from two factors: diversity and customer needs changing [47]. 
Table 2. Characteristics of the five first-tier equipment suppliers.

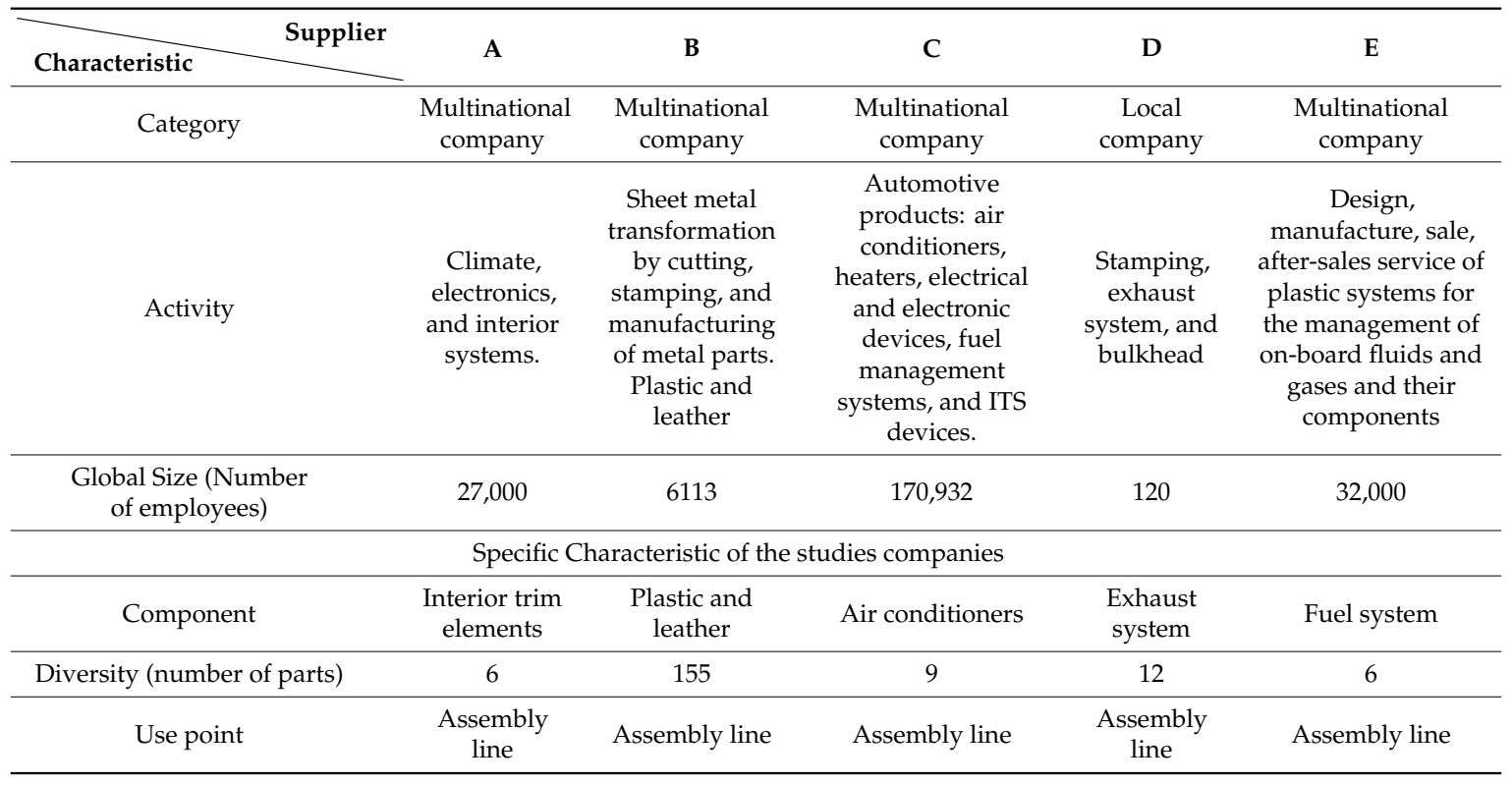

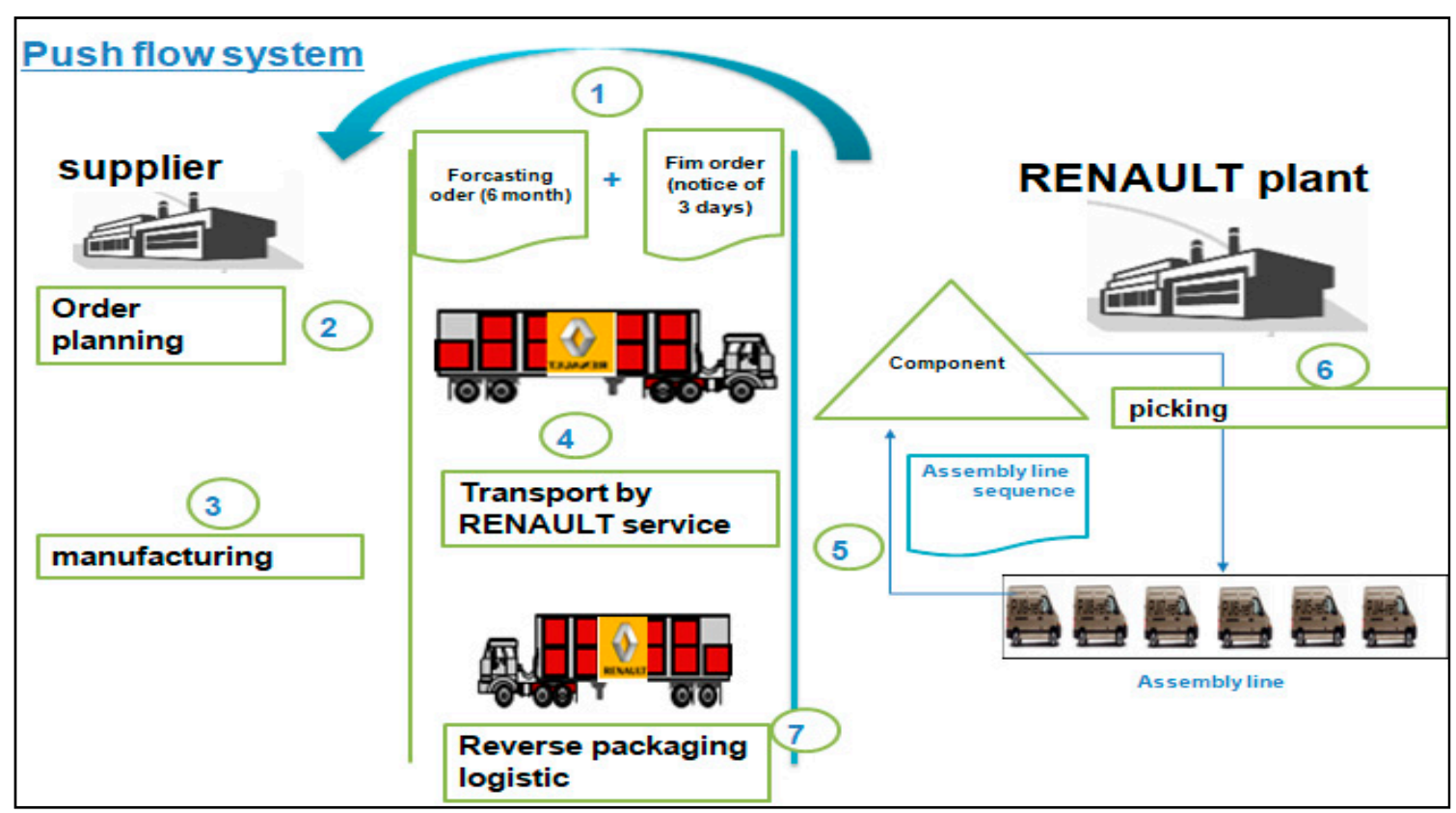

Figure 4. Current push flow with suppliers.

The project's essence is to study the possibility of implementing the synchronous flow between RENAULT's plant and suppliers. Synchronization concerns components' flow from suppliers and vehicle sequence in the final stage of the assembly process. Implementing the synchronous link "Input Assembly" mainly concerns the voluminous and/or highly diversified parts. As explained in Figure 5; suppliers will receive two types of requests from the plant. A provisional request gives information about all flows located on upstream of the assembly line. This information allows suppliers to organize and make production planning. The second request is the firm requisition order, and it is issued when the vehicle passes through the "assembly entry" point. The firm requisition order represents the only information that triggers the supplier's supply of the assembly line. In synchronous flow, all the logistics picking is outsourced to the suppliers who deliver ready-made handling units directly to the workplace. As mentioned in Figure 6, the handling unit becomes multi-reference. 


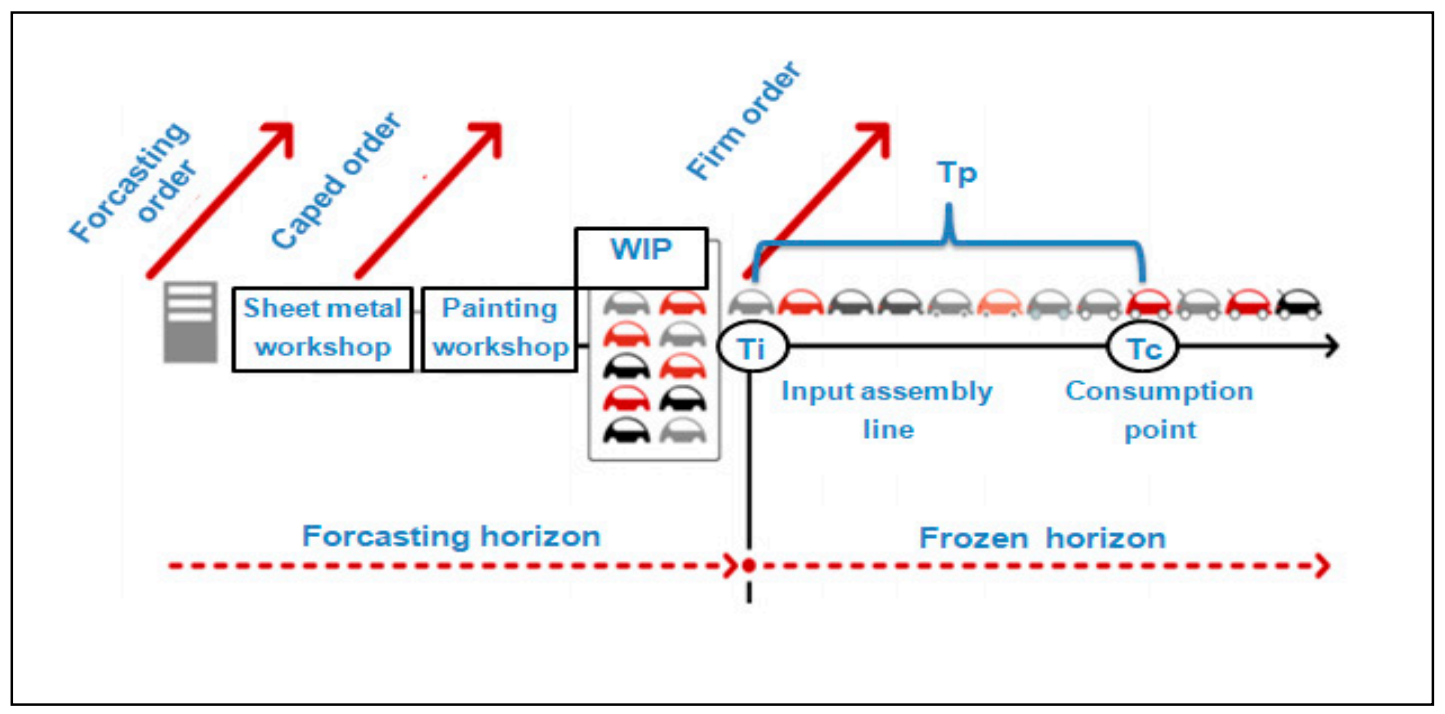

Figure 5. Synchronous flow mechanism. Source: adapted from RENAULT document.

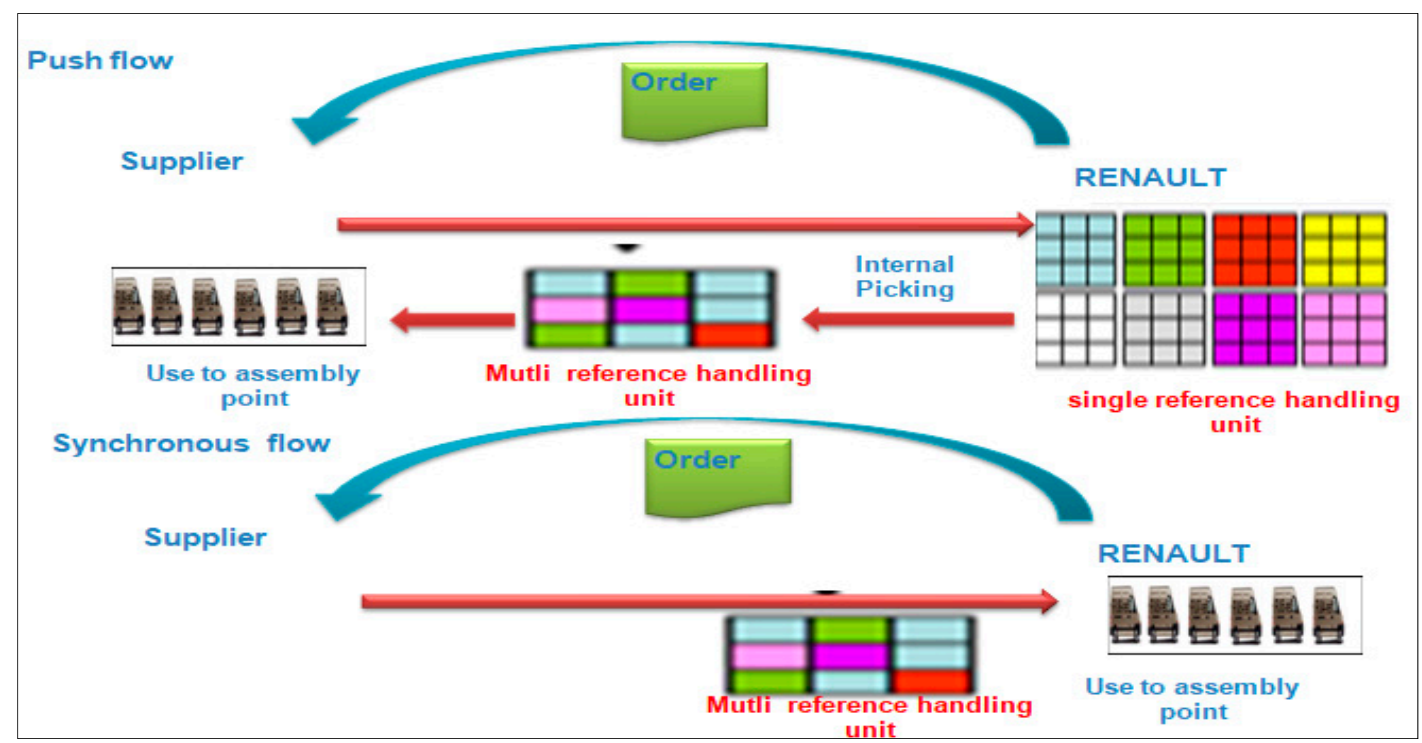

Figure 6. Handling unit composition.

In this type of flow, the frozen horizon becomes very short (a few hours). The time available to the supplier to prepare a packaging and ship the parts directly to the assembly point (Tp) corresponds to the time between the moment when the vehicle enters assembly (Ti) and that of its passage at the assembly point of the delivered part synchronously (Tc). That is why proximity is the first criteria to be fulfilled in a synchronous flow. According to RENAULT's service, less than $5 \mathrm{~km}$ must separate the plant and suppliers.

\subsection{Data Collection Process}

Data collection processes used the following sources: semi-structured interviews, consultation of internal RENAUTLT's documents, and observations. Semi-structured interviews allow collecting data by interviewing participants using an interview guide [48], which contains all covered topics (Table 3). The interview guide was elaborated based on the literature review, which identified motivators, barriers, benefits, and prerequisites for implementing synchronous flow. On the side of the client plant (RENAULT's plant), the interviews were carried out with several participants in different departments—namely purchasing managers of each equipment manufacturer, plant logistics manager, 
supply manager, transportation manager, engineering department, human resources department, IT department, and environment department. On the supplier's side, the logistics manager was the primary contact designated as the project manager. Participants were met individually at their offices. The interviews were started by introducing the study's objective and asking for permission to record the interviews. At the end of each interview, the participants had the opportunity to add other elements not discussed and which can serve to deepen the study. The interviews lasted, on average, between 30 to $60 \mathrm{~min}$. A thematic analysis was carried out for data analysis. The recorded interviews were transcribed, and the exciting features of the textual data were coded using QSR NVivo 10 qualitative data analysis software.

Table 3. Interview guide.

\begin{tabular}{cc}
\hline Participant & Collected Data \\
\hline Supplier Project manager & Location requirements \\
\cline { 2 - 2 } & Handling unit requirements \\
\hline Plant supply manager & Cost structure \\
\hline Purchasing department & Suppliers selection \\
\cline { 2 - 2 } Transport manager & Negotiation elements \\
\hline Supply manager & Current transportation value \\
\hline IT department & RENAULT's network connection device \\
\hline HR department & Necessary configuration of the logistic system \\
\hline Environment department & Requirements to manage supplier staff in plant \\
\hline Engineering department & Environment requirements \\
\cline { 2 - 2 } & Flow circulation requirements \\
\cline { 2 - 2 } & Packaging requirements \\
\hline & Handling requirements \\
\hline
\end{tabular}

\section{Results}

\subsection{Application of the Preliminary Framework}

In this subsection, the elaborated preliminary framework of Figure 2 is applied to study the possibilities of implementing synchronous flow with the five equipment suppliers. In-depth practical investigations have brought out other constructs to consider. Table 4 summarizes the application of the three first steps of the preliminary framework. Regarding the proximity criterion, it was necessary to split the study into two parts.

Through the proposed framework for supporting the adoption of a collaborative supply chain with a focus on supply chain lean practice, different aspects of motivators are analyzed to encourage companies' involvement with suppliers and thus to allow the initiation of the collaboration in the supply chain. Following this analysis, the motivators of launching the collaboration prospect are varied and led us to their classification into two categories-economic and organizational motivators. Economic motivators are identified through optimization of inventory level within supply chain prospect. For that purpose, optimization must be achieved in a win-win perspective concurrently with the customer and the supplier. Organizational motivators are reflected through increased flexibility and reactivity, especially in the automotive context characterized by the demand uncertainty. 
Table 4. Application of the preliminary framework.

\begin{tabular}{|c|c|c|c|c|c|}
\hline & A & B & $\mathrm{C}$ & D & E \\
\hline $\begin{array}{l}\text { Economic } \\
\text { motivators }\end{array}$ & $\begin{array}{l}\text { Optimization } \\
\text { of inventory } \\
\text { level within the } \\
\text { supply chain }\end{array}$ & $\begin{array}{l}\text { Optimization } \\
\text { of inventory } \\
\text { level in the } \\
\text { supply chain }\end{array}$ & $\begin{array}{l}\text { Optimization } \\
\text { of inventory } \\
\text { level in the } \\
\text { supply chain }\end{array}$ & $\begin{array}{l}\text { Optimization } \\
\text { of inventory } \\
\text { level in the } \\
\text { supply chain }\end{array}$ & $\begin{array}{l}\text { Optimization } \\
\text { of inventory } \\
\text { level in the } \\
\text { supply chain }\end{array}$ \\
\hline $\begin{array}{c}\text { Organizational } \\
\text { motivators }\end{array}$ & $\begin{array}{l}\text { Flexibility and } \\
\text { reactivity }\end{array}$ & $\begin{array}{l}\text { Flexibility and } \\
\text { reactivity }\end{array}$ & $\begin{array}{l}\text { Flexibility and } \\
\text { reactivity }\end{array}$ & $\begin{array}{l}\text { Flexibility and } \\
\text { reactivity }\end{array}$ & $\begin{array}{c}\text { Flexibility and } \\
\text { reactivity }\end{array}$ \\
\hline $\begin{array}{c}\text { Suppliers } \\
\text { Categorization }\end{array}$ & strategic & strategic & strategic & strategic & strategic \\
\hline $\begin{array}{l}\text { Presence of } \\
\text { Drivers }\end{array}$ & yes & yes & yes & yes & yes \\
\hline $\begin{array}{l}\text { Proximity to } \\
\text { plant }\end{array}$ & $500 \mathrm{~km}$ & $400 \mathrm{~km}$ & $400 \mathrm{~km}$ & $20 \mathrm{~km}$ & $230 \mathrm{~km}$ \\
\hline $\begin{array}{c}\text { Proximity } \\
\text { Action plan }\end{array}$ & $\begin{array}{l}\text { Study a second } \\
\text { type of } \\
\text { synchronous } \\
\text { flow with a } \\
\text { firm request } \\
\text { from sheet } \\
\text { metal } \\
\text { workshop }\end{array}$ & $\begin{array}{l}\text { Study a second } \\
\text { type of } \\
\text { synchronous } \\
\text { flow with a } \\
\text { firm request } \\
\text { from sheet } \\
\text { metal } \\
\text { workshop }\end{array}$ & $\begin{array}{l}\text { Study a second } \\
\text { type of } \\
\text { synchronous } \\
\text { flow with a } \\
\text { firm request } \\
\text { from sheet } \\
\text { metal } \\
\text { workshop }\end{array}$ & $\begin{array}{l}\text { Study the } \\
\text { possibility of } \\
\text { locating the } \\
\text { supplier in the } \\
\text { plant. }\end{array}$ & $\begin{array}{l}\text { Study a second } \\
\text { type of } \\
\text { synchronous } \\
\text { flow with a } \\
\text { firm request } \\
\text { from sheet } \\
\text { metal } \\
\text { workshop }\end{array}$ \\
\hline
\end{tabular}

The practical investigation showed that it is judicious to categorize the suppliers before considering eligibility for the synchronous flow. Suppliers categorization was done according to the Kraljic Matrix [49-52]. According to the purchasing department's interviews, we concluded that all suppliers are classified as strategic suppliers. Their impact on profit is considerable, given the relatively high purchase price and the consumption rate. On the supply risk side, suppliers' scarcity and the criticality of the parts they deliver are two factors making them at high risk. Suppliers can be qualified as a single source. The literature on suppliers' categorization shows that maintaining relationships is the best strategy for this category. Implementing supply chain lean practice is a way to achieve this relationship.

According to Table 4, after testing the proximity requirements, we deducted those for all the suppliers except suppliers D. The synchronous flow from assembly line input will not be possible, so a second type of synchronous will be tested for those suppliers. Consequently, it is synchronous with the sheet metal input. In what follows, we separated the two studies, respectively, into two studies: S1: synchronous input metal sheet tested with suppliers A, B, C and E; S2: synchronous input assembly line tested with supplier $\mathrm{D}$. As proximity requirements were decisive, subsequent studies consist of applying other elements of the preliminary framework, namely information-sharing requirements, resource requirements, KPI, and continuous improvement. Accordingly, for each supplier, those key elements will be tested with the aim is to verify the possibility of implementing synchronous flow and, if necessary, identify the barriers preventing this implementation. To this end, data collected from interviews and observations were compiled to answer each key element. Results are exposed in the following sections in table form, giving the decision about implementation possibility of synchronous flow.

\subsection{S1: Synchronous Input Metal Sheet Study (Suppliers A, B, C, and E)}

As mentioned previously, this type of synchronous flow was tested with four suppliers: A, B, C, and $\mathrm{E}$. The flow is programmed, based directly on the vehicle film's firming and the emission of a firm message by vehicle to the supplier. These firm messages are accompanied by a forecast order in gross need grouped by production day and by chain. The Frozen period (horizon of which the needs and orders are firm and unchangeable) begins from the sheet metal workshop, which is two working 
days. Figure 7 explains this mechanism. Since firm order is based on the initial vehicle sequence, the principal condition to achieve this synchronous flow is the respect of the vehicle sequence from sheet metal to assembly line. This respect is measured by SSAR (Standard Sequence Achievement Ratio). This measures the percentage of vehicles that keep their place between the time they go into production and the time they are finished. This rate reflects the capacity to meet operations planning. According to Renault's instructions, to accomplish a synchronous flow according to the initial sequence, SSAR must be more than $95 \%$. Otherwise, the sequenced deliveries from the suppliers will not be adapted to the flow of vehicles.

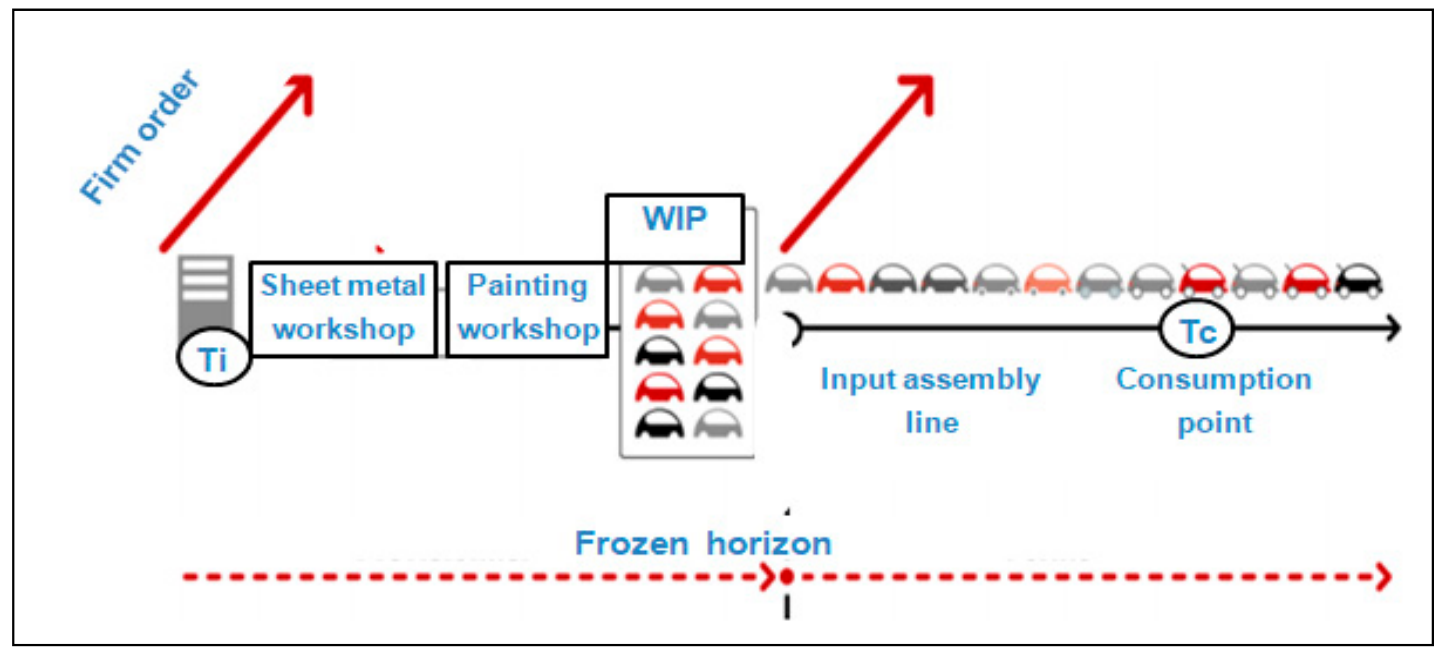

Figure 7. Synchronous input metal mechanism.

After applying elements from the preliminary framework, and from Table 5, we conclude that none of the four suppliers has been selected for the synchronous flow. Financial benefits that can RENAULT achieve from the synchronous flow is between EUR 20,000 and EUR 27,000. It includes the average inventory cost. Information sharing is achieved since the four suppliers have a certified information system specific to synchronous flow. They can receive all required orders via an integrated system. Nevertheless, two principal criteria were unpromising:

1. Resource: the principal resource here is the handling unit. This unit must be multi-reference and be suitable to support all shapes of parts at the same time. For two suppliers, the current handling unit is inadequate for such flow. Regarding the estimated benefits, the investment amount is not justified.

2. Planning achievement: this is about SSAR; unfortunately, in the Renault plant, this rate is below the required level.

Table 5. Synchronous input metal study.

\begin{tabular}{ccccc}
\hline & A & B & C & E \\
\hline Benefits in inventory & EUR 27,000 & EUR 21,000 & EUR 20,000 & EUR 20,000 \\
\hline Information sharing requirement & $\checkmark$ & $\checkmark$ & $\checkmark$ & $x$ \\
\hline $\begin{array}{c}\text { Resources requirements } \\
\begin{array}{c}\text { Action plan }=\text { investment to adapt } \\
\text { handling unit }\end{array}\end{array}$ & EUR 255,000 & 0 & 0 & EUR 22,000 \\
\hline SSAR & $x$ & $x$ & $x$ & $x$ \\
\hline Final decision & $x$ & $x$ & $x$ & $x$ \\
\hline
\end{tabular}




\subsection{S2: Synchronous Input Assembly Line (Suppliers D)}

The following section is devoted to testing the possibility of implementing synchronous flow from assembly line input with Supplier D. In the same way as other suppliers, elements of the preliminary framework will be applied. Benefits and requirements will be evaluated, and a decision will be made to implement or not synchronous flow.

Figure 8 explains the projected flow to achieve with suppler D. The supplier will continuously receive forecasts from RENAULT's service planning (1). Those forecasts are used to plan the upstream of the supply chain (2), (3). A delivery flow between supplier D plant and its workshop in the RENAULT plant serve to supply components required for manufacturing operations (4), (5). A firm requisition is sent to the supplier via the printer each time a vehicle is captured at the entrance to the assembly line (6). Then, picking from the inventory is done according to the firm order and every exhaust system component is designed for a specific vehicle and identified with the equivalent VIN (Vehicle Identification Number) (7). Finally, a reverse logistic flow concerns empty packaging to supplier D plant (8).

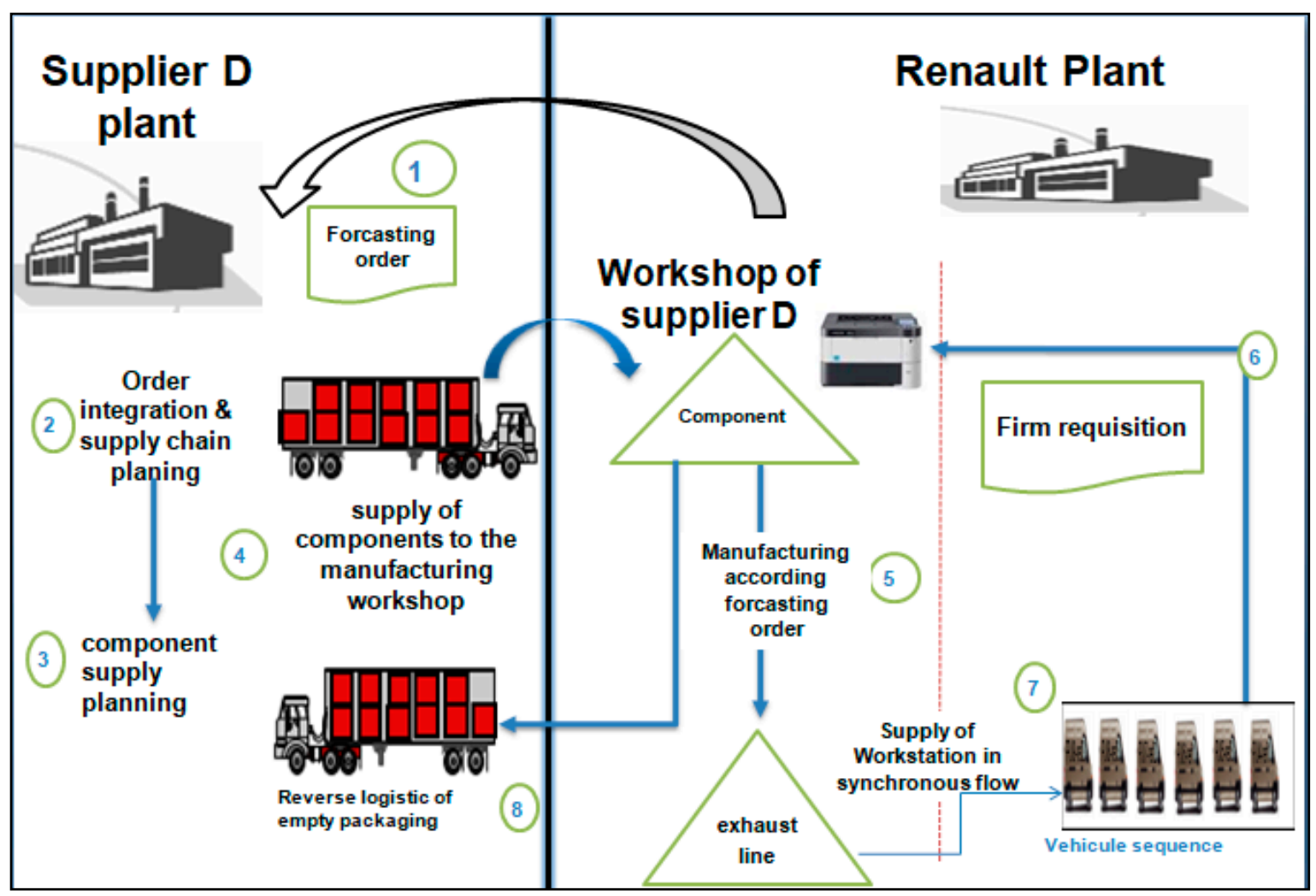

Figure 8. Synchronous flow in the plant for supplier D.

\subsubsection{Benefits}

According to the preliminary framework, the implementation of synchronous flow starts absolutely with benefits highlighting. Here, only financial benefits are discussed. From a lean perspective, benefits come from cost and waste avoiding. Regarding flow, the idea is to analyze all costs which can be avoiding through synchronous flow implementation. All benefits are summarized in Table 6, and singly explained as follows:

1. Inventory Financial Cost: With the synchronous flow, there would be no stock of exhaust lines in the RENAULT plant, and zero stock is reached. The stock's financial cost is calculated according to the rate of return on capital practiced by the banks. As Morocco's interest rate is about 5\%, 
and with an average annual inventory amount of EUR 149,292 financial savings from inventory is about EUR 74,646 per year.

2. Inventory Deterioration Cost: It is incurred due to the deterioration of the parts while staying in stock. This cost depends on the nature of the part. Exhaust Systems, the subject of the present study, are very exposed to oxidation. As mentioned in Table 6, the cost related to waste because of oxidation is about EUR 6,600,000 per year. This represents the cumulative value of all the quantity of parts damaged during the year.

3. Upstream Transport Cost: In push flow, Renault supports the upstream transport reserved for the exhaust system. In the case of synchronous flow, this type of transport will no longer be supported by the plant; consequently, all the cost is considered a benefit.

4. Human Resource Cost: In push flow, the picking agent is present to prepare the handling unit adequate to the vehicle sequence. In synchronous flow, this task will be done by the supplier so that RENAULT will save the salary of the picking agent.

By analyzing the expected benefits structure, it is noticed that they are high due to inventory-related costs. Especially deterioration cost with $98 \%$. As mentioned previously, Exhaust System is very exposed to oxidation. It should be noted that an oxidized part is irreparable and is automatically confused. Consequently, a financial loss is generated equivalent to the purchase price of the part. The loss becomes more and more consequent when it comes to an expensive part and represents a significant percentage of the vehicle's price, as is the case for the exhaust line. One of the best solutions to avoid this waste is limiting the constitution of stock as much as possible and to tend towards 0 stock. This solution can be achieved through the synchronous flow since the supply flow will be precisely synchronized with the parts' consumption flows, and the stock of the exhaust lines would be eliminated.

Table 6. Benefits from synchronous flow with supplier D.

\begin{tabular}{ccc}
\hline $\mathbf{N}^{\circ}$ & Elements & Annual Amount (Euros) \\
\hline 1 & Financial cost & 74,646 \\
\hline 2 & Inventory deterioration cost & $6,600,000$ \\
\hline 3 & Upstream transportation fees & 67,782 \\
\hline 4 & Human resource for Handling & 37,752 \\
\hline
\end{tabular}

\subsubsection{Requirements and Investments}

Hereabouts, all investments required for implementation are evaluated. Table 7 summarized those elements:

1. Proximity action plan: The first requirement to be studied is proximity. This supplier is located at $20 \mathrm{~km}$ from the plant. Depending on the part's assembly point, the supplier has only $2 \mathrm{~h}$ $(\mathrm{Tc}-\mathrm{Ti}=120 \mathrm{~min}$ ) to prepare and deliver a complete exhaust package. To overcome this constraint, the supplier was welcomed to the RENAULT plant's premises, installing its production and delivery units according to the following guidelines:

- Installation of suppliers in the same industrial park as the manufacturer.

- The supplier will transfer its activity to the manufacturer's plant.

- The supplier will use its resources to provide components.

All fees related to room layout and rent is in charge of RENAULT for whom it costs nothing since the premises are already fitted out and fully amortized.

2. Information sharing: Initially, the suppliers must be linked to the client factory's information system via an internet application. The application requires an investment, in our case. Since the 
supplier is located in the client's site, the solution was to link the supplier to the customer network via a physical cable by installing printers used to print requisition orders. Information on the progress of the firm film and the current vehicle sequences are provided daily by the IT department via email.

3. Resources: both human and material resources are concerned.

- Material resources: These are packages that must be multi-reference to support all the diversity of exhaust lines at the same time. There is also the tractor, which would be used to handle these packages to the workstation.

- Human resources: this consists of recruiting a workshop foreman and physical flow agent dedicated to this flow.

- Training: Working in synchronous flow differs from normal flow; this requires special training for all the team dedicated to this flow. RENAULT's services provided the training.

4. Safety/environment specifications: Since RENAULT is ISO14000 certified, and the supplier settles on the customer's site, the supplier must comply with the requirements of this certification. Requirements aim to protect welding stations through fire-resistant curtains, extraction at the source for the smoke emitted from the welding, either by extractors or by a suction torch. The supplier has agreed to take charge of all related investments.

Table 7. Investments for synchronous flow with supplier D.

\begin{tabular}{|c|c|c|c|c|}
\hline $\mathbf{N}^{\circ}$ & Investments & Element & $\begin{array}{l}\text { Annual Amount } \\
\text { (Euros) }\end{array}$ & $\begin{array}{c}\text { Total Annual } \\
\text { Amount (Euros) }\end{array}$ \\
\hline 1 & Proximity action plan & room layout rent & 0 & 0 \\
\hline \multirow{2}{*}{2} & \multirow{2}{*}{$\begin{array}{l}\text { Information sharing } \\
\text { requirement }\end{array}$} & printer & 4500 & \multirow{2}{*}{4500} \\
\hline & & other information sharing & 0 & \\
\hline \multirow{7}{*}{3} & \multirow{7}{*}{ Resources } & Human & & \multirow{7}{*}{206,000} \\
\hline & & team leader & 10,000 & \\
\hline & & handling agent & 180,000 & \\
\hline & & training & 0 & \\
\hline & & \multicolumn{2}{|l|}{ Physical } & \\
\hline & & Handling Equipment & 6000 & \\
\hline & & Picking trolley & 10,000 & \\
\hline 4 & Environment & $\begin{array}{l}\text { Fire-resistant curtains, } \\
\text { extraction at the source for the } \\
\text { smoke emitted from the } \\
\text { welding, either by extractors } \\
\text { or by a suction torch. }\end{array}$ & 0 & 0 \\
\hline
\end{tabular}

\subsubsection{Final Decision and Implementation}

After analyzing expected benefits and investments, a decision has to be made about the implementation or not of synchronous flow. Table 8 shows all the elements identified and presents the balance between gain and investment. Regarding the benefits, and as mentioned previously, inventory is a significant cost item, mostly due to the high deterioration risk of the exhaust system. Considering the investments induced by requirements, the information sharing tool represents only $2 \%$ of total investment cost, taking into account the simple solution chosen to link suppliers with the plant information system. The important part of investments is in other resources. There is the recruitment of specific teams regarding this project and specific handling material. Compliance with environmental requirements could have constituted a hefty cost item for the customer if the supplier had not taken 
the initiative to take charge of it. The final decision was a convenient agreement to start the project with an annual global net benefit of approximately EUR 6500. Regarding vehicle transformation cost, RENAULT can save approximately EUR 75/vehicle.

Table 8. Balance of implementing synchronous flow with supplier D.

\begin{tabular}{ccc}
\hline & Annual Amount (Euros) & Balance (Euros) \\
\hline Benefits & $67,129,986$ & $6,502,499$ \\
\cline { 1 - 2 } Investment & 210,500 & \\
\hline Final decision & OK for implementation \\
\hline
\end{tabular}

According to the preliminary framework (Figure 2), two constructs are to be achieved after implementation: Suppliers performance measurement system and continuous improvement practice.

1. Performance measurement: from the previous literature review, an appropriate performance measurement system is a vital driver in a supply chain relation [53]. According to Bigliardi and Bottani [54], supplier performance measurement indicators are among a whole supply chain performance measurement system. They are summarized in: efficiency, responsiveness, reliability, and price offered [55]. For RENAULT, equipment suppliers' performance is measured by service rate, document accuracy, logistic quality, product quality, and price productivity. These indicators join those identified in the literature. In the specific case of synchronous flow, the supplier is judged only on the logistics quality, price, and product quality. This difference comes from the fact that integration with the supplier reaches the ultimate point in the synchronous flow, which is reflected in the performance indicators. The respect of the delivery time is no longer a significant criterion since the delivery delay is intolerable. The supplier delivers the components directly for use, so there is no margin to absorb any delay. Documentation accuracy serves to guarantee the documentary reliability, which is used to feed the stock status. In synchronous flow, the stock no longer exists, so this indicator is no longer useful. Table 9 illustrates the evolution of indicators from a high flow to synchronous flow.

2. Continuous improvement: To ensure continuous improvement, it is necessary to permanently and systematically identify the failures and risks which can block the fluidity of the flow. Hence, we have proposed an audit tool and a tool for risk management.

- Self-audit tool

Table 9. Comparison of Indicators.

\begin{tabular}{cccc}
\hline Indicators & Objective & Push Flow & Synchronous Flow \\
\hline Service rate & Measure respect of delivery time & $\checkmark$ & $x$ \\
\hline Documentation accuracy & Guarantee inventory update reliability & $\checkmark$ & $\checkmark$ \\
\hline Logistic quality & $\begin{array}{c}\text { Measure logistical incidents, such as } \\
\text { chain shutdown or missing }\end{array}$ & $\checkmark$ & $\checkmark$ \\
\hline Price & Capacity to optimize continuously the & $\checkmark$ & $\checkmark$ \\
\hline Product quality & Compliance with quality requirements. & $\checkmark$ & $\checkmark$ \\
\hline
\end{tabular}

Continuous self-audit is an effective way to guarantee the continuity of a system [56]. It makes it possible to detect faults and correct them permanently. We have proposed an audit tool to verify the correct application of all the synchronous flow requirements. We designed it in light of the interviews with the various actors who expressed, each in their field, the critical points which risk blocking 
the fluidity of flows. Table 10 shows the audit tool organized in five axes: firm film, information, human resources, handling material, and procedures. For each question, an actor is designed as responsible for answering it.

Table 10. Self-audit tool. Source: Ibn El Farouk and Jawab [8].

\begin{tabular}{|c|c|c|c|}
\hline \multicolumn{4}{|c|}{ Self-Audit Checklist } \\
\hline Process & & Supply Mount Point in a Synchronous Flow & \\
\hline $\mathbf{N}^{\circ}$ & Parameters & Questions & Actor \\
\hline 1 & \multirow{2}{*}{ Firm film } & $\begin{array}{l}\text { What is the information procedure you are applying in } \\
\text { case of changing the firm film? }\end{array}$ & $\begin{array}{c}\text { Logistic } \\
\text { department }\end{array}$ \\
\hline 2 & & $\begin{array}{l}\text { How do you guarantee the real-time } \\
\text { information-sharing on the film firm with the supplier? }\end{array}$ & $\begin{array}{c}\text { Logistic } \\
\text { department }\end{array}$ \\
\hline 3 & \multirow{6}{*}{ Information } & $\begin{array}{l}\text { What is the frequency of preventive control you have } \\
\text { planned for the printer? }\end{array}$ & Supplier \\
\hline 4 & & Do you have a back-up printer on-site? & Supplier \\
\hline 5 & & $\begin{array}{l}\text { How do you ensure the printer's continuous supply } \\
\text { of consumables? }\end{array}$ & Supplier \\
\hline 6 & & $\begin{array}{l}\text { Do you meet the quality requirements of } \\
\text { consumables used? }\end{array}$ & Supplier \\
\hline 7 & & How do you act in any failure of network connection? & Supplier \\
\hline 8 & & How a network failure is handled? & IT \\
\hline 9 & \multirow{3}{*}{ Handling } & $\begin{array}{l}\text { How do you guarantee the maintenance of the } \\
\text { delivery trolleys? }\end{array}$ & Supplier \\
\hline 10 & & $\begin{array}{l}\text { How do you guarantee the maintenance of } \\
\text { self-propelled tractors? }\end{array}$ & Supplier \\
\hline 11 & & $\begin{array}{l}\text { How is your trolley loop calculated? How do you } \\
\text { update it? }\end{array}$ & Supplier \\
\hline 12 & Procedure & $\begin{array}{l}\text { How do you ensure the application of business } \\
\text { requirements at the workplace? }\end{array}$ & Supplier \\
\hline 13 & \multirow[b]{2}{*}{ Human resources } & How do you manage the versatility of the picking post? & Supplier \\
\hline 14 & & $\begin{array}{l}\text { Do you guarantee that the picking agent is constantly } \\
\text { present next to the printer? }\end{array}$ & Supplier \\
\hline
\end{tabular}

\section{- Risk management tool}

The synchronous flow saves costs related to inventory management, but this strength constitutes, at the same time, its weakness. The absence of the stock makes the system very weak and sensitive to the slightest disturbance. The most severe risk that may arise is the disruption of the assembly line replenishment. With zero safety stock, the only consequence is the production activity shutdown, which is considered an intolerable incident due to the immense losses. The risk analysis we have associated with this project would help control this risk and avoid it happening. The idea is to manage risks by identifying their possible causes and controlling them by implementing appropriate action plans. In this regard, a Fault Tree Analysis of deliveries breakdown was made thanks to brainstorming that led to a mapping of undesirable events to be monitored (Figure 9). Those events concern three axes: information-sharing, inventory management, and resource availability. Information-sharing includes two elements: network quality and material availability. Network quality can be considered an external factor, under which both the supplier and RENAULT have no control. Contrariwise, material availability, especially printer, is the supplier's responsibility. Inventory management aim at managing operations to guarantee a smooth flow of material from upstream to downstream. Effective inventory management must avoid an out-of-stock situation and also guarantee financial savings. Resources availability concerns both material and human resources. Human resources are the 
most critical key in any lean practice since those practices require more rigor, implication, and special skills. As mentioned previously, synchronous flow requires a specific handling tool whose availability ensures the assembly line's continuity. Thus, it is vital to guarantee a rigorous management system of those tools, especially regular maintenance operations.

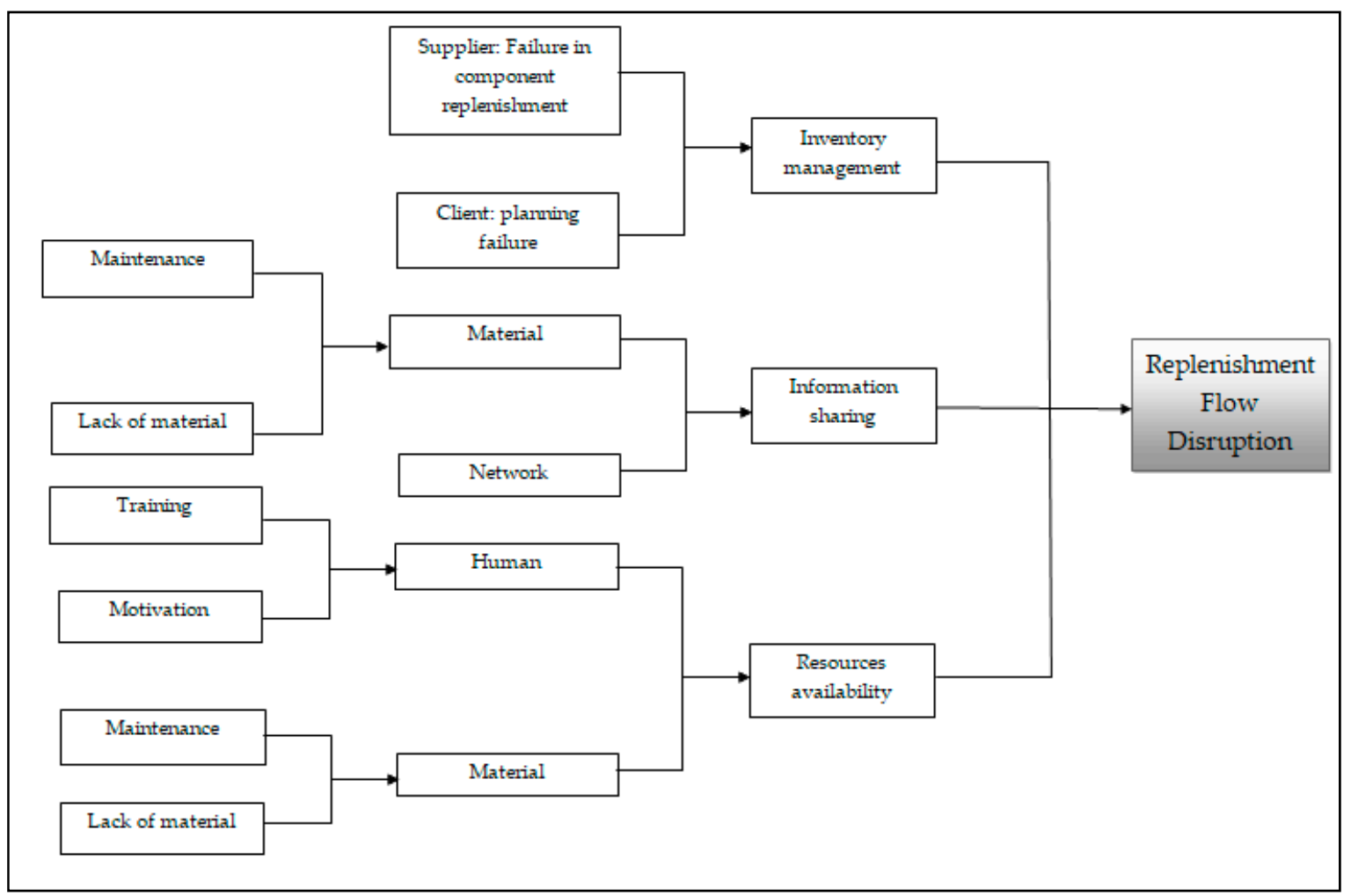

Figure 9. Risks mapping. Source: adapted from Ibn El Farouk and Jawab [8].

The preliminary framework's application on the case study has revealed other essential factors that should be taken into consideration in the implementation of synchronous flow within a supply chain. Thus, the preliminary framework was revisited and improved. The resulting framework is provided in Figure 10. 


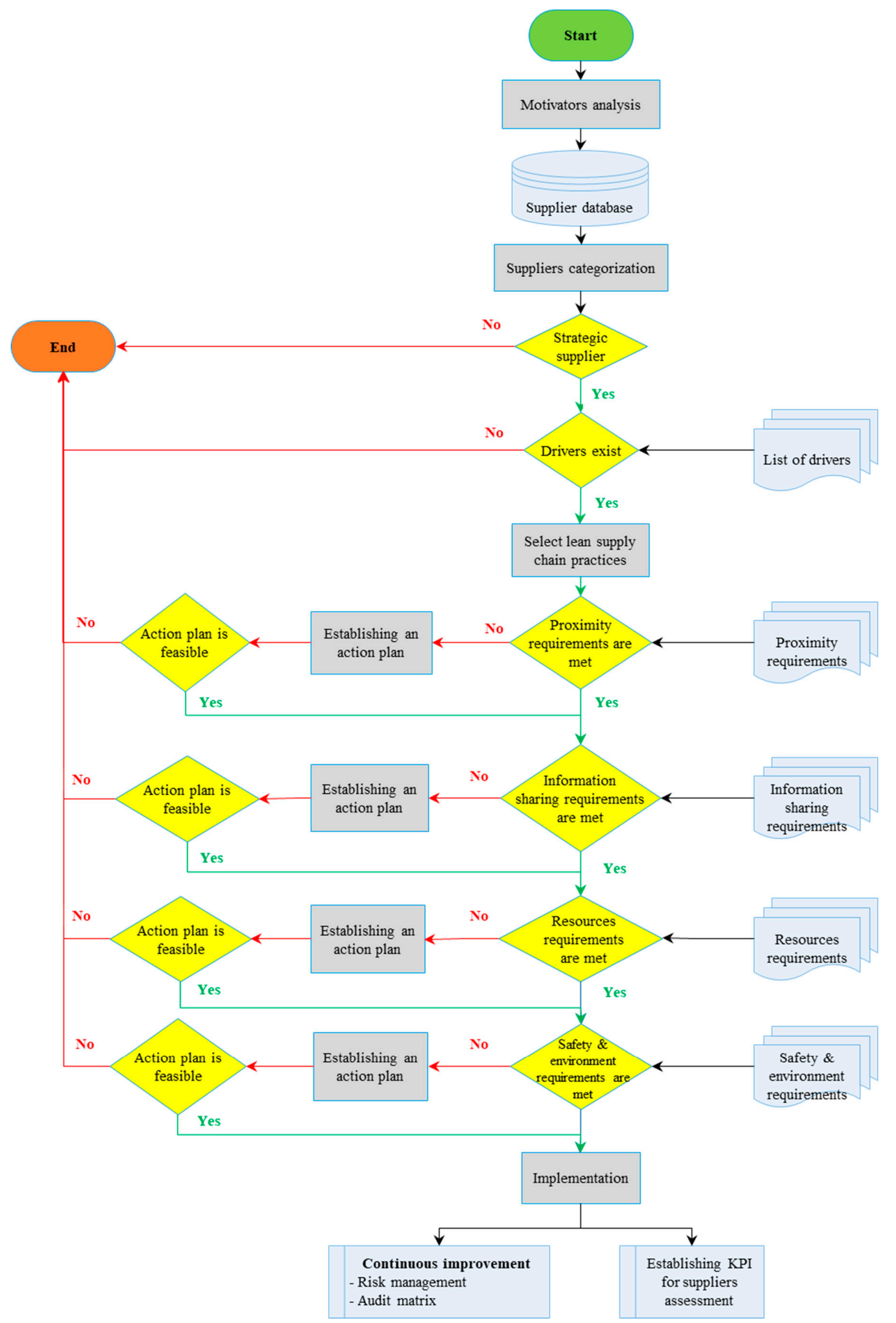

Figure 10. Proposed supply chain collaboration framework for the implementation of synchronous flow. 


\section{Discussion}

Through the proposed framework to support the implementation of synchronous flow, via collaborative practice between a car manufacturer and component suppliers, the lessons can only be numerous and constructive. The financial balance was clearly in favor of the project. However, the financial dimension would not have been sufficient without a firm commitment from the customer and the supplier to bring this project to fruition. A commitment reflected in that of all the teams whose conviction of the well-founded nature of the project has made it a success. It can be confirmed that mutual trust between customer and supplier has amply increased the project's success chances. The supplier settled on the client's premises without being worried about losing his know-how, and the client was ready enough to welcome the supplier and put in place all the favorable conditions for its installation. The second crucial lesson is that the supplier's size is not a determining criterion for starting a collaborative practice. Among the five suppliers involved in the study, the only selected one with whom the project worked was the smallest supplier. Additionally, it is the supplier with the oldest relationship with the client.

Through this study, it can be confirmed that collaboration, especially in lean practice, should be considered particularly with strategic suppliers. In the present case study, the delivered component and the exhaust line, is a critical component for the assembly process with a high price, which represents a considerable impact on the profit margin. Additionally, supply sources are scarce in this sector.

In this study, two frameworks were proposed. The preliminary framework, resulting from the literature review, highlighted the main elements to be considered and monitored during a lean supply chain collaborative practice. The second framework enriched the first one with specific construct to the case study, namely, the need to categorize the suppliers before starting such a practice, considering the sustainability data reflected in the framework with respect to environmental standards. Risk management and establishing an audit system are two tools that will guarantee the continuity of the system after its start-up.

Finally, a specific effort has to be made concerning the mutation of the supplier measurement performance system. As it has been advanced, this system was completely changed after the implementation of synchronous flow. Thanks to this project, supplier-customer relation has evolved, and the traditional performance indicators have become obsolete.

\section{Conclusions}

This study's objective was to analyze a collaborative practice within the framework of the synchronous flow between the automotive manufacturer and its equipment manufacturers. Two frameworks were proposed. The first one resulted from a literature review that focused on supply chain collaboration and lean practices between supplier and customer. Through this preliminary framework, the primary constructs of a lean supply chain collaboration were identified and organized in a decision support tool that can orient the efforts during the implementation of synchronous flow. Regarding the specificity of synchronous flow, the practical experimentation was essential to enrich the preliminary framework. The experiment was carried out in the form of a case study, consisting of a RENAULT's plant and five of its equipment manufacturers. The obtained result, namely the revised framework, confirmed the critical aspect of trust, commitment, and information sharing as a pillar of all collaborative practices. The conducted case study enriched the catalog of practices to be adopted with strategic suppliers. The safety and environment data were strongly highlighted and only confirmed the obligation to make all the lean project stakeholders adhere to the same requirements. Another important conclusion is the change in the performance measurement system after joining a lean supply chain project. This change reveals that performance measurement is a fundamental management tool for customer-supplier relationships within the supply chain. It is not fixed but evolves with the maturity of this relationship.

As a perspective and as part of a win-win approach, the flow must evolve towards synchronous production. In this way, the stock level would be optimized even on the supplier side. Synchronous 
production would only be possible if the manufacturing cycle time is less than the Tc-Ti interval. This objective necessitates the deployment of more lean manufacturing practices to improve the production flow by eliminating non-value-added steps.

Author Contributions: Conceptualization, I.I.E.F., I.M., Y.F., J.A. and F.J.; Data curation, I.I.E.F., I.M. and Y.F.; Formal analysis, I.I.E.F., I.M., Y.F. and J.A.; Investigation, I.I.E.F., I.M., Y.F. and J.A.; Methodology, I.I.E.F., I.M., Y.F. and J.A.; Project administration, I.I.E.F., I.M., Y.F., J.A. and F.J.; Resources, I.I.E.F., I.M, Y.F. and J.A.; Software, Y.F.; Validation, I.I.E.F., I.M., Y.F. and J.A.; Visualization, F.J.; Writing—original draft, I.I.E.F., I.M., Y.F. and J.A.; Writing-review \& editing, I.I.E.F., I.M., Y.F. and J.A. All authors have read and agreed to the published version of the manuscript.

Funding: This research received no external funding.

Acknowledgments: The authors would like to thank the participants from the studied companies for their availability, precious time, and valuable contribution.

Conflicts of Interest: The authors declare no conflict of interest.

\section{References}

1. Sahoo, S. Assessing lean implementation and benefits within Indian automotive component manufacturing SMEs. Benchmarking Int. J. 2020, 27, 1042-1084. [CrossRef]

2. Manfredsson, P.; Hilletofth, P.; Reitsma, E. Involving suppliers in a lean training program. In Proceedings of the 9th International Conference on Operations and Supply Chain Management, Cranfield, UK, 15-18 December 2019.

3. Ambe, I.M.; Badenhorst-Weiss, J.A. An automotive supply chain model for a demand-driven environment. J. Transp. Supply Chain Manag. 2011, 5, 1-22. [CrossRef]

4. Kotcharin, S.; Eldridge, S.; Freeman, J. The relationship between lean supply chain strategy and supplier integration and competitive capabilities in Thailand's automotive supplier. In Proceedings of the Decision Sciences Institute 43rd Annual Meeting, San Francisco, CA, USA, 16-22 November 2012.

5. Guo, Y.; Xu, Z. A model of lean supplier management based on the lean production. Res. Pract. Issues Enterp. Inf. Syst. II 2007, 254, 717-726.

6. Tuli, P.; Shankar, R. Collaborative and lean new product development approach: A case study in the automotive product design. Int. J. Prod. Res. 2015, 53, 2457-2471. [CrossRef]

7. Huang, Y.; Han, W.; Macbeth, D. The complexity of collaboration in supply chain networks: An exploratory study of the Chinese automotive sector. Supply Chain Manag. Int. J. 2020, 25, 393-410. [CrossRef]

8. El Farouk, I.I.; Jawab, F. Synchronous flow in automotive industry: Case study of RENAULT. In Proceedings of the 2017 International Colloquium on Logistics and Supply Chain Management (LOGISTIQUA), Rabat, Morocco, 27-28 April 2017; pp. 199-203.

9. Lynch, J. Contemporary Operations and Logistics: Achieving Excellence in Turbulent Times. In Contemporary Operations and Logistics: Achieving Excellence in Turbulent Times; Springer International Publishing: New York, NY, USA, 2019; pp. 193-218.

10. Mofokeng, T.M.; Chinomona, R. Supply chain partnership, supply chain collaboration and supply chain integration as the antecedents of supply chain performance. South Afr. J. Bus. Manag. 2019, 50, 1-10. [CrossRef]

11. Singh, P.J.; Power, D. The nature and effectiveness of collaboration between firms, their customers and suppliers: A supply chain perspective. Supply Chain Manag. Int. J. 2009, 14, 189-200. [CrossRef]

12. Simatupang, T.M.; Sridharan, R. Design for supply chain collaboration. Bus. Process. Manag. J. 2008, 14, 401-418. [CrossRef]

13. Derrouiche, R.; Neubert, G.; Bouras, A. Supply chain management: A framework to characterize the collaborative strategies. Int. J. Comput. Integr. Manuf. 2008, 21, 426-439. [CrossRef]

14. De Freitas, D.C.; de Oliveira, L.G.; Alcântara, R.L.C. A theoretical framework to adopt collaborative initiatives in supply chains. Gest. Prod. 2019, 26,1-15. [CrossRef]

15. Frichi, Y.; Kacem, A.B.; Jawab, F.; Kamach, O.; Chafik, S. Improving Interhospital Medical Patient Transportation in Morocco: A Forecasting Collaborative Approach. In Transportation, Logistics, and Supply Chain Management in Home Healthcare: Emerging Research and Opportunities; Euchi, J., Ed.; IGI Global: Hershey, PA, USA, 2020; pp. 136-162. 
16. Arif, J.; Azzouz, K.; Mouzouna, Y.; Jawab, F. Design on improvement of traceability process in the outsourcing of logistics' activities using the internet of things (IoT) applications. Int. J. Adv. Sci. Technol. 2020, 29, 1093-1108.

17. Singh, H.; Garg, R.K.; Sachdeva, A. Supply chain collaboration: A state-of-the-art literature review. Uncertain Supply Chain Manag. 2018, 6, 149-180. [CrossRef]

18. Marqui, A.C.; de Moura, K.S.; Alcântara, R.L.C. Collaborative supply chain: A conceptual model for operationalisation. Int. J. Manag. Decis. Mak. 2013, 12, 195-214. [CrossRef]

19. Ma, K.; Pal, R.; Gustafsson, E. What modelling research on supply chain collaboration informs us? Identifying key themes and future directions through a literature review. Int. J. Prod. Res. 2018, 57, 2203-2225. [CrossRef]

20. Spekman, R.E.; Spear, J.; Kamauff, J. Supply chain competency: Learning as a key component. Supply Chain Manag. An Int. J. 2002, 7, 41-55. [CrossRef]

21. Jawab, F.; Talbi, A.; Bouami, D. Le réapprovisionnement continu dans les réseaux industriels, vers une meilleure gestion des interfaces de la «supply chain ». Rev. des Sci. Gest. 2006, 2, 123-137.

22. Jawab, F.; Bouami, D. La démarche supply chain management enjeux et stratégies, cas du commerce électronique et de la grande distribution. Rev. Sci. Gest. Dir. Gest. 2004, 1, 95-109. [CrossRef]

23. Ahn, G.; Park, Y.J.; Hur, S. Probabilistic graphical framework for estimating collaboration levels in cloud manufacturing. Sustainability 2017, 9, 277. [CrossRef]

24. Saenz, M.J.; Ubaghs, E.; Cuevas, A.I. Vertical Collaboration and Horizontal Collaboration in Supply Chain. In Enabling Horizontal Collaboration Through Continuous Relational Learning; Springer: Cham, Switzerland, 2015; pp. 7-10.

25. De Freitas, D.C.; de Oliveira, L.G.; Alcantara, R.L.C. Collaborative initiatives: Motivators, barriers and benefits. Rev. Adm. Mackenzie 2018, 19. [CrossRef]

26. Al-Doori, J.A. The impact of supply chain collaboration on performance in automotive industry: Empirical Evidence. J. Ind. Eng. Manag. 2019, 12, 241-253. [CrossRef]

27. Vargas, A.; Patel, S.; Patel, D. Towards a business model framework to increase collaboration in the freight industry. Logistics 2018, 2, 22. [CrossRef]

28. Arif, J.; el Farouk, I.I.; Mouzouna, Y.; Jawab, F. The use of internet of things (IoT) applications in the logistics outsourcing: Smart RFID tag as an example. In Proceedings of the International Conference on Industrial Engineering and Operations Management, Bangkok, Thailand, 5-7 March 2019; pp. 291-300.

29. Wu, I.L.; Chuang, C.H.; Hsu, C.H. Information sharing and collaborative behaviors in enabling supply chain performance: A social exchange perspective. Int. J. Prod. Econ. 2014, 148, 122-132. [CrossRef]

30. Panahifar, F.; Byrne, P.; Salam, M.A.; Heavey, C. Supply chain collaboration and firm performance: The critical role of information sharing and trust. J. Enterp. Inf. Manag. 2017, 31, 358-379. [CrossRef]

31. Ogunmola, O.S.; Arogundade, K.K. Effects of supply chain DESIGN and collaboration on customers' satisfaction of instant noodles in Ekiti State, Nigeria. Logistics 2019, 3, 2. [CrossRef]

32. Vanichchinchai, A. The effect of lean manufacturing on a supply chain relationship and performance. Sustainability 2019, 11, 5751. [CrossRef]

33. Arif, J.; Jawab, F. Outsourcing of logistics' activities: Impact analysis on logistics service performance. In Proceedings of the 2018 International Colloquium on Logistics and Supply Chain Management (LOGISTIQUA), Tangier, Morocco, 26-27 April 2018; pp. 88-92.

34. Giard, V.; Mendy, G. De l'approvisionnement synchrone à la production synchrone dans la chaine logistique. Rev. Française Gest. 2007, 2, 68-88. [CrossRef]

35. Colomb, P.; Devulder, C. Mise en place des flux synchrones dans l'industrie automobile: Cas d'un équipementier sur le site de Renault Brésil. Logistique Manag. 1998, 6, 31-40. [CrossRef]

36. Gallois, P.-M.; Devulder, C.; Ferreira, S. Global synchronous manufacturing and logistics organization: A success story. Supply Chain Forum Int. J. 2000, 1, 59-69. [CrossRef]

37. Singh, R.K.; Modgil, S. Assessment of lean supply chain practices in Indian automotive industry. Glob. Bus. Rev. 2020, 1-39. [CrossRef]

38. Boonsthonsatit, K.; Jungthawan, S. Lean supply chain management-based value stream mapping in a case of Thailand automotive industry. In Proceedings of the 2015 4th IEEE International Conference on Advanced Logistics and Transport, IEEE ICALT 2015, Valenciennes, France, 20-22 May 2015; pp. 65-69.

39. Mayer, J.A.; Borchardt, M.; Pereira, G.M. Methodology for the collaboration in supply chains with a focus on continuous improvement. Ing. Investig. 2016, 36, 51-59. [CrossRef] 
40. Salonitis, K.; Tsinopoulos, C. Drivers and barriers of lean implementation in the Greek manufacturing sector. In Proceedings of the 49th CIRP Conference on Manufacturing Systems, Stuttgart, Germany, 25-27 May 2016; Volume 57, pp. 189-194.

41. Wu, Y.C. Lean manufacturing: A perspective of lean suppliers. Int. J. Oper. Prod. Manag. 2003, 23, 1349-1376.

42. Schuh, G.; Stüer, P. Framework for lean management in industrial services. In IFIP Advances in Information and Communication Technology in Production Management Systems; Springer: Berlin/Heidelberg, Germany, 2012; pp. 392-398.

43. Piekkari, R.; Welch, C.; Paavilainen, E. The case study as disciplinary convention: Evidence from international business journals. Organ. Res. Methods 2009, 12, 567-589. [CrossRef]

44. Seawright, J.; Gerring, J. Case selection techniques in case study research: A menu of qualitative and quantitative options. Political Res. Q. 2008, 61, 294-308. [CrossRef]

45. Tomski, P. On Case Study Method in Entrepreneurship Research. Zesz. Nauk. Politech. Częstochowskiej Zarzadzanie 2017, 27, 189-198. [CrossRef]

46. Jasti, N.V.K.; Kodali, R. A literature review of empirical research methodology in lean manufacturing. Int. J. Oper. Prod. Manag. 2014, 34, 1080-1122. [CrossRef]

47. Achrol, R.S.; Stern, L.W. Environmental determinants of decision-making uncertainty in marketing channels. J. Mark. Res. 1988, 25, 36-50. [CrossRef]

48. Frichi, Y.; Jawab, F.; Boutahari, S. An exploratory qualitative study of the influence of hospital logistics factors on quality of care and patient satisfaction at public hospitals in Morocco. Adv. Sci. Technol. Eng. Syst. J. 2019, 4, 414-422. [CrossRef]

49. Glöckner, H.-H.; Pieters, R.; de Rooij, W. Importance of the Kraljic matrix as a strategic tool for modern purchasing. LogForum 2005, 1, 1-11.

50. Saueressig, G.G.; de Paris, A.; Bauer, J.M.; Luchese, J.; Sellitto, M.A.; Antunes, J.A.V. Strategic materials positioning matrix: An application in the automotive industry in Southern Brazil. Int. J. Ind. Eng. Manag. 2017, 8, 77-89.

51. Gelderman, C.J.; Donald, D.R.M. Application of Kraljic's purchasing portfolio matrix in an undeveloped logistics infrastructure: The staatsolie suriname case. J. Transnatl. Manag. 2008, 13, 77-92. [CrossRef]

52. Caniëls, M.C.J.; Gelderman, C.J. Purchasing strategies in the Kraljic matrix-A power and dependence perspective. J. Purch. Supply Manag. 2005, 11, 141-155. [CrossRef]

53. Moufad, I.; Jawab, F. A study framework for assessing the performance of the urban freight transport based on PLS approach. Arch. Transp. 2019, 49, 69-85. [CrossRef]

54. Bigliardi, B.; Bottani, E. Supply chain performance measurement: A literature review and pilot study among Italian manufacturing companies. Int. J. Eng. Sci. Technol. 2014, 6, 1-16. [CrossRef]

55. Moufad, I.; Jawab, F. The determinants of the performance of the urban freight transport-An empirical analysis. In Proceedings of the 2018 International Colloquium on Logistics and Supply Chain Management, LOGISTIQUA, Tangier, Morocco, 26-27 April 2018; pp. 99-104.

56. Arif, J.; El Farouk, I.I.; Jawab, F. Logistic Outsourcing: From the Contracts Complexity to the Logistic Services Performance. In Proceedings of the International Conference on Industrial Engineering and Operations Management, Bandung, Indonesia, 6-8 March 2018; pp. 3247-3257.

(C) 2020 by the authors. Licensee MDPI, Basel, Switzerland. This article is an open access article distributed under the terms and conditions of the Creative Commons Attribution (CC BY) license (http://creativecommons.org/licenses/by/4.0/). 